\title{
Karsten Reise \\ Coast of change: habitat loss and transformations in the Wadden Sea
}

Received: 31 July 2004 / Revised: 10 October 2004/ Accepted: 20 October 2004/Published online: 18 January 2005

(c) Springer-Verlag and AWI 2005

\begin{abstract}
In the southern North Sea, coastal people commenced with habitat conversions 1,000 years ago. Partly interrupted in late medieval times by large-scale inundations of marshland, progressive embankments transformed the landward half of the amphibic transition zone between a limno-terrestric and a brackishmarine ecosystem into arable land and freshwater lakes. Sea walls rigidly separated the land from the sea. Dynamic transitional habitats have vanished. Areal loss has diminished the capacity of the Wadden Sea to dissipate wave and tidal energy. A coastal ecosystem once rich in marsh plants, seagrass and diatoms on mud flats became transformed into one with less autochthonous phototroph production, dominated by sandy tidal flats, and dependent primarily on allochthonous plankton supply. The large estuaries have been dredged to serve as shipping canals, and have lost most of their former retention and filter capacity. Riverine loads are now flushed right into the North Sea. Symptoms of a syndromatic coastal habitat degradation are diagnosed, leading to a decline in natural habitat diversity. The conventional on-line coastal protection may not achieve a sustainable coastal habitat configuration. At sedimentary coasts immobilised by dikes and petrified shores, a more flexible response to sea level rise is recommended.
\end{abstract}

Keywords Coastal dynamics - Estuary - Habitat loss · Sea level rise $\cdot$ Tidal flats

Communicated by H.K. Lotze

K. Reise

Alfred Wegener Institute for Polar and Marine Research, Wadden Sea Station Sylt, 25992, List, Germany

E-mail: kreise@awi-bremerhaven.de

Tel.: +49-4651-956110

Fax: +49-4651-956200

\section{Introduction}

Sea level rise and sediment supply have been the main drivers of change in coastal morphology of the southern North Sea until diking commenced about 1,000 years ago (Behre 2002; Flemming and Davis 1994; Pethick 2001; Rippon 2000; Wolff 1992a). Here, an attempt is made to reconstruct natural states before diking became the key process affecting habitat diversity in the Wadden Sea region. Similar developments took place at the east coast of Britain (Burbridge and Pethick 2003), in China (Wang et al. 2000) and elsewhere at sedimentary coasts. However, the tradition of gaining and separating land from the Wadden Sea has come to an end (Wolff 1992b). During the 1980s, natural wetlands came to be valued more highly than a potential gain from turning them into arable land. Nevertheless, further embankments and storm surge barriers were employed for improving water management in the hinterland and for the sake of coastal defence. The present coastal defence policy is to hold the line. The Netherlands, Germany and Denmark have adopted a common management plan for integrating nature conservation and human use in the Wadden Sea (Stade Declaration 1998).

What is the outcome of coastal transformations on habitat diversity and natural habitat dynamics? The large areal extent of embankments also poses the question whether the tidal area of the Wadden Sea, if left to itself, will remain as it is or is there a legacy of past interventions by which habitats will continue to change? This is to be expected if present coastal morphology is not in line with hydrodynamic conditions. Further, sea level is assumed to continue to rise, presumably with some acceleration (IPCC 2001). Will this cause tidal flats to fade away and muddy sediments to become more sandy? Habitats also change when habitat generating species (ecosystem engineers, sensu Jones et al. 1994), such as seagrasses, oysters and mussels, are affected (Lotze 2005; Wolff 2005). 
Abrahamse (1976), Bantelmann (1966), Behre (2001, 2002), van Eerden et al. (1997) and Knottnerus (2001) provide reconstructions of historical Wadden Sea landscapes. First surveys on habitats in the tidal area were conducted in the 1920s and 1930s (i.e., Hagmeier and Kändler 1927; Nienburg 1927; Wohlenberg 1937; Linke 1939; Plath 1943). Comprehensive habitat maps for the 1970s have been provided by Dijkema (1983, 1991; Dijkema et al. 1989) and a status list of biotopes and biotope complexes has been compiled by Ssymank and Dankers (1996). Habitats are here defined as conspicuous, recurrent areal components with a characteristic cluster of hydrographic, morphological, sedimentary and biotic features.

I will focus on the tidal area and shoreline habitats, consider effects of past sea level change, and speculate on the functioning of the primordial Wadden Sea coastal ecosystem. In a second part, I describe transformations towards modern coastal architecture and reflect on a syndromatic development that has arisen. I conclude with a few suggestions for future habitat management in the Wadden Sea.

\section{Areal overview}

In former times, the Wadden Sea region continued into the Rhine delta and beyond, but at present it is understood as the $500-\mathrm{km}$ long coastal zone between the Marsdiep in the west and Grådyb in the north (Fig.1; Anonymous 1991; De Jong et al. 1993, 1999; Wolff 1983). It is still one of the largest coherent tidal flat areas in the world. Nowadays, a mainland coastal plain of about $24,000 \mathrm{~km}^{2}$ comprises $15,000 \mathrm{~km}^{2}$ of embanked marshes and embayments (including the former Zuiderzee), $1,000 \mathrm{~km}^{2}$ of islands and high sandy shoals, $200 \mathrm{~km}^{2}$ of salt marshes along the mainland coast and

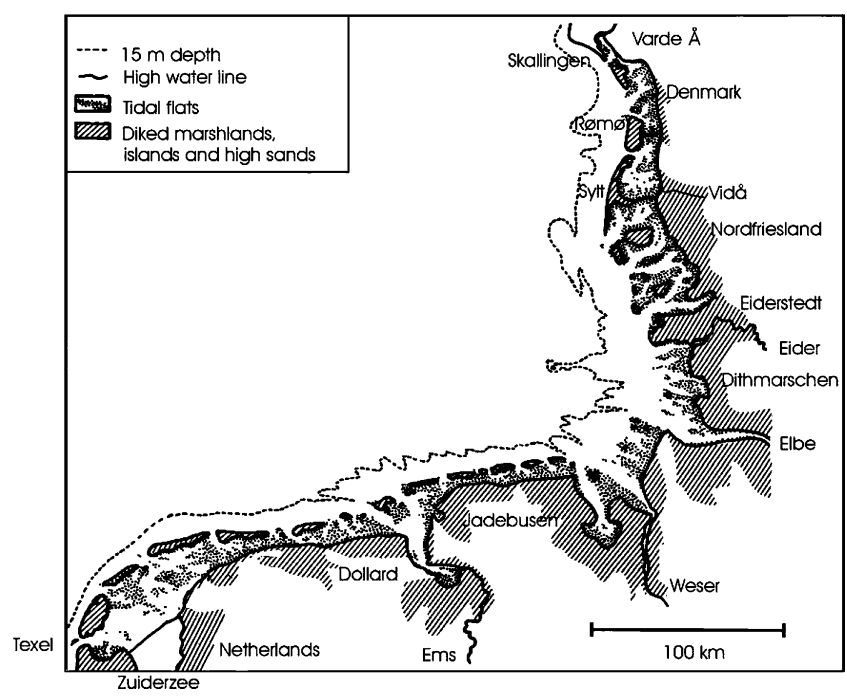

Fig. 1 The Wadden Sea between the 15-m depth contour and the embanked marshland, with the former Zuiderzee area and part of the Elbe estuary cut off

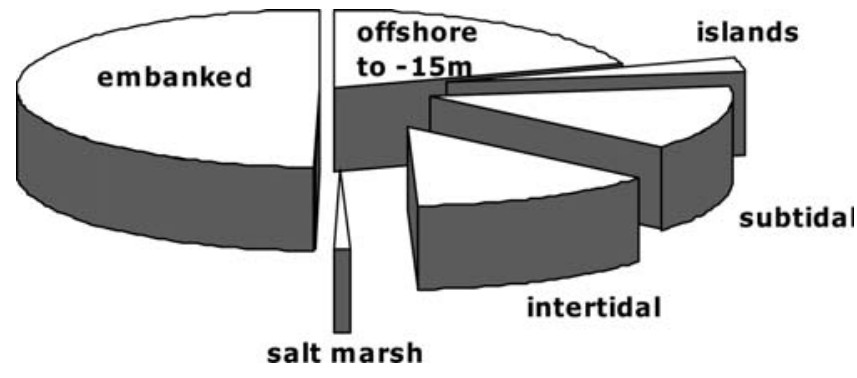

Fig. 2 Areal share of land- and sea-scape components in the Wadden Sea region, including the Zuiderzee area

$100 \mathrm{~km}^{2}$ on the islands, $4,000 \mathrm{~km}^{2}$ of intertidal sand and mud flats, and also $4,000 \mathrm{~km}^{2}$ of a sandy subtidal zone dissected by deep tidal channels (gulleys) and inlets (Fig. 2). About $6,000 \mathrm{~km}^{2}$ of the adjacent North Sea down to a depth of $-15 \mathrm{~m}$ may be added to include the immediate sharing system of sediment and water.

A thousand years ago, before people started to transform this coastal landscape, salt marshes, brackish reed marshes, lagoons, bogs and lakes comprised approximately $14,650 \mathrm{~km}^{2}$. These are now embanked, including some tidal areas. In the northern Wadden Sea, the tidal area used to be smaller than it is now, but may have extended further seaward to an unknown extent. Today, the tidal area of the entire Wadden Sea is presumably close to its size before 1000 AD.

In medieval times, areal proportions were changed intermittently by storm surges inundating embanked land which had been artificially subsided by cultivation and peat mining (Table 1). These inundations occurred at different times between 1000 and $1634 \mathrm{AD}$, earliest in the southwest and latest in the north of the Wadden Sea. Subsequent re-embankments followed the same pattern. The largest embayment which came into existence was the brackish Zuiderzee $\left(3,600 \mathrm{~km}^{2}\right)$. When it was dammed in 1932, almost one-third of the entire tidal area of the Wadden Sea had been cut off, and was subsequently converted into arable land and a freshwater lake.

\section{Rise and fall of sea level in a pristine Wadden Sea}

Since the end of last glaciation in $16,000 \mathrm{BP}$, relative sea level has risen by $120 \mathrm{~m}$ in the North Sea region (Behre 2002; Rippon 2000; Streif 1989). During a fast rise until

Table 1 Estimated areal sizes of medieval inundations of mostly cultivated marsh and peatland (IMP) between 1000 and 1634 AD, of their partial re-embankment, of the still inundated parts now belonging to the tidal area, and that part of the tidal area which became embanked, but never had been medieval marshland. Given as percentages of all former marshes and bogs $\left(14,650 \mathrm{~km}^{2}\right)$

\begin{tabular}{lll}
\hline Type of area & $\mathrm{km}^{2}$ & $\%$ \\
\hline Inundated marsh and peatland (IMP) & 6,200 & 42 \\
Re-embanked IMP & 5,180 & 35 \\
Remaining IMP & 1,020 & 7 \\
Embanked primordial tidal area & 1,370 & -
\end{tabular}


7000 BP, tundra and boreal forest in the southern North Sea became flooded. When the shoreline approached the region of the present Wadden Sea, sea level was still $>10 \mathrm{~m}$ lower than today and the rise decelerated. Short phases of stasis or fall occurred intermittently. A switch from transgression to 200 years of regression occurred around the beginning of the Christian calendar. This interval was followed by a rise of roughly $2 \mathrm{~m}$ until today (Rippon 2000).

When sea level rise slowed down, barrier spits with sand dunes developed. These were eventually breached and cut into barrier islands as sea level continued to rise and tidal range increased. In the southern Wadden Sea, this happened between 7500 and $6000 \mathrm{BP}$ and constitutes the birth of the coastal configuration of the Wadden Sea (Flemming 2002). In the central Wadden Sea, marsh and tidal deposits accumulated in front of pleistocene elevations, and no permanent seaward barrier developed. In the northern part, a tidal area extended behind protruding pleistocene islands which developed long sandy spits, forming a barrier similar to the islands in the south (Bantelmann 1966).

The ratio between external sediment supply and the sediment deficits entailed by sea level rise differed between subregions. Together with tidal range, this determined long-term coastal developments (Ehlers 1988; Louters and Gerritsen 1994; Oost and de Boer 1994). The tidal area behind barrier islands gradually enlarged with sea level rise. When sea level rise stopped intermittently (i.e., $100 \mathrm{BC}$ to $100 \mathrm{AD}$ ), the tidal area probably decreased, and then increased again when sea level rise continued. Landward of the tidal area, a marsh of a similar areal extent provided a wide episodically flooded plain, consisting of saltmarsh vegetation and brackish to limnic reed marshes, including raised bogs. Particularly at the edge of pleistocene elevations, extensive freshwater peat bogs developed. Along major rivers, gallery forests occurred at the levees (Behre 2002). Otherwise the marsh was a treeless plain kept open by episodic flooding.

The total area from the barrier islands over the tidal area and the open marsh plain to the glacial moraines remained about the same from $4000 \mathrm{BC}$ to $1000 \mathrm{AD}$, while the position of the shoreline between tidal area and salt marsh was highly dynamic and shifted back and forth with sea level and sediment supply.

\section{Functioning of the primordial coastal ecosystem}

Episodic marine intrusions transported fine sediment particles and organic carbon of marine origin far inland. A dense vegetation and elevated berms at the seaward edges of salt and river marshes retained this material. Similarly, rivers deposited particle loads in the reed marshes behind the levees. Rivers had ramifications and inner deltas, which functioned as an effective filter for riverine waters before entering the Wadden Sea. Most of what was carried downstream by rivers was probably retained in the wide estuaries and their flood plains.
Below neap high tide level, salt and reed marshes gave way to extensive mud flats. The waters above may have been relatively transparent most of the time, because of: (1) the riverine filters, (2) a high energy dissipation and deposition capacity of the wide flood plain, and (3) vast oyster beds between Britain and the Wadden Sea (Olsen 1883). Their filtering capacity may have caused clearer waters than nowadays, when the waters are without oysters but with anthropogenic eutrophication. Therefore, seagrass beds may have been very extensive (Fig. 3) and would have served as an additional sink for fine particles. A modern analogue may be the pristine tidal area of the Banc d'Arguin in Mauretania mostly covered by seagrasses (Wolff et al. 1993). Not only the intertidal zone but also the subtidal was suitable for extensive seagrass beds. These also stabilised sediment, were rich in associated species, and served as spawning grounds for herring (De Jonge and de Jong 1992; Philippart et al. 1992; van Katwijk 2003; Wohlenberg 1935).

Conspicuous biogenic habitats were mussel beds (Mytilus edulis) in the lower intertidal to upper subtidal zone, oyster beds (Ostrea edulis) in the shallow subtidal and along deep channels, and reefs $0.5 \mathrm{~m}$ high were built by the colonial polychaete Sabellaria spinulosa (Fig. 3; Hagmeier and Kändler 1927; Wolff 2005). These suspension feeder assemblages provided a substrate for macroalgae and other sessile invertebrates. Thus, in spite of being a sedimentary coast, the primordial Wadden Sea was rich in epibenthic habitat structures, particularly in its subtidal zone, mitigating sediment mobility and increasing biodiversity.

The extensive mud flats imply a high carrying capacity for higher trophic levels. Salt marshes were not only large, but also rich in residual water bodies, creeks, ponds and puddles, and along the mainland showed various transitions over brackish to limnic waters with the corresponding sequences of biota. Waterbirds would have found a wide and diverse habitat. With extensive

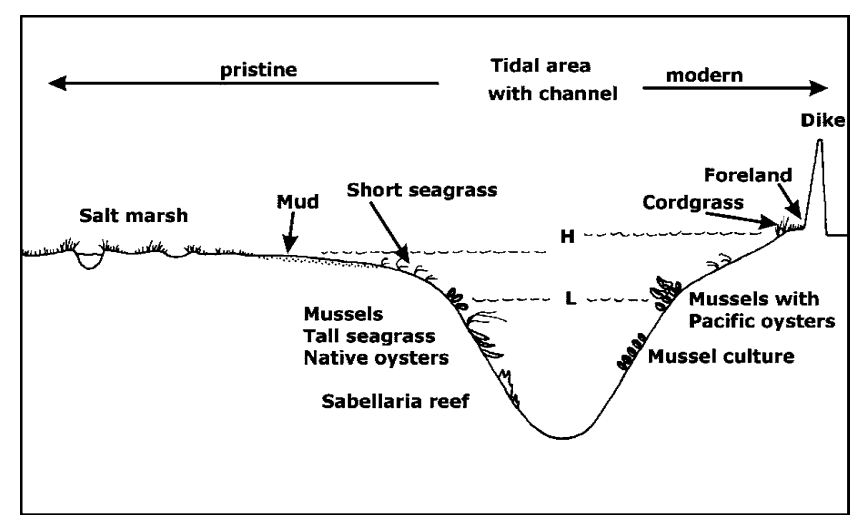

Fig. 3 Schematic cross section through a tidal channel with adjacent tidal area in primordial (left) and modern time. $H$ and $L$ high and low tide level, respectively. Note that $H$ but not $L$ has risen over time. Cordgrass $S$. anglica; short seagrass includes intertidal Zostera noltii and $Z$. marina; tall seagrass subtidal $Z$. marina; mussels $M$. edulis; native oysters $O$. edulis; Pacific oysters C. gigas; a polychaete worm $S$. spinulosa 
salt marshes, seagrass beds, and mud flats rich in microphytobenthos, the primordial Wadden Sea ecosystem had a high share of phototrophs, entailing assemblages of grazers and surface deposit feeders. It is suggested that the primordial ecosystem of the Wadden Sea may have relied primarily on its autochthonous production, subsidised by a low to moderate import of phytoplankton from the North Sea.

\section{Transformations towards modern coastal architecture and habitat composition}

When large scale human impacts on habitats commenced about 1,000 years ago, these generally progressed from the land towards the open sea, and diversified and intensified over time (Fig. 4). A mainly autochthonous brackish to marine coastal ecosystem with an extensive flood plain became transformed into a marine fringe of the North Sea, relying on allochthonous supply.

\section{Sea level rise and coastal defence}

When comparing shorelines 1,000 years apart one needs to consider the relative change in sea level. From historical documents since 1570 AD (i.e., marks on buildings), Rohde (1977) infers an increase in the peak levels of storm surges by $0.2-0.3 \mathrm{~m}$ per century. This is similar to recent gauge measurements which indicate an increase of $0.20-0.25 \mathrm{~m}$ in high tide level over the last century (CPSL 2001), and is also similar to global sea level rise of 1.5-2.0 mm per year obtained from gauge records or of $\sim 2.5 \mathrm{~mm}$ per year from ongoing satellite altimeters for the period 1993-2003 (Miller and Douglas 2004). Since $1500 \mathrm{AD}$, a cumulative rise by $1.0-1.5 \mathrm{~m}$ in high tide level has occurred, and for the time since 1000 AD the upper estimate might be the best guess. In the absence of sea defences, such an increase could cause a conspicuous retreat of the shoreline and a concomitant rise in marsh level by natural deposition. Assuming a rate of transgression in the order of $10 \mathrm{~m}$ horizontally

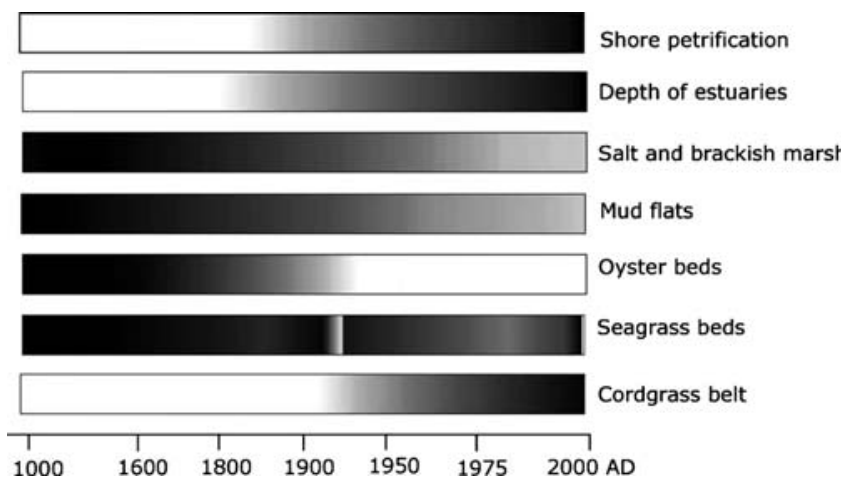

Fig. 4 Selected trends in the fate of relative length, depth or extent of habitats in the Wadden Sea over the past 1,000 years. Time AD on log scale (increase darken, decrease lighten) for every $1 \mathrm{~mm}$ of sea level rise, as calculated by Pethick (2001) for the Humber estuary, the present shoreline would have been $15 \mathrm{~km}$ further inland than it was at 1000 AD. However, diking has in many cases moved the modern shoreline further seaward instead.

Crucial for an understanding of long-term trends in shoreline development is the relation between sea level change, sediment availability under natural conditions and when dikes protect the land against flooding (CPSL 2001; Louters and Gerritsen 1994; Oost and de Boer 1994). The development of tidal areas is largely determined by the ratio between the increase in water volume associated with sea level rise and the sediment volume supplied from external sources. With an excess of sediment supply, as at the Dithmarschen coast just north of the Elbe estuary, shores are accreting in spite of sea level rise. Where sediment supply is lower, however, tidal areas are expanding by shoreline erosion. This serves as a source of sediment, raising the level of the nearshore zone to keep pace with sea level rise (Fig. 5; see Bruun rule: French 2001; Pugh 2004). A dike in tidal areas with sediment deficiency will cause a squeeze of upper shore habitats until these are lost. Increasing hydrodynamics prevent fine sediment particles from settling and eventually tidal flats will fade away. This process is exacerbated where dikes have been built below high tide level. The confrontation between land and sea becomes focussed at the foot of the dike which then needs to be defended with hard structures. These replace an entire sequence of natural shoreline habitats. Such a

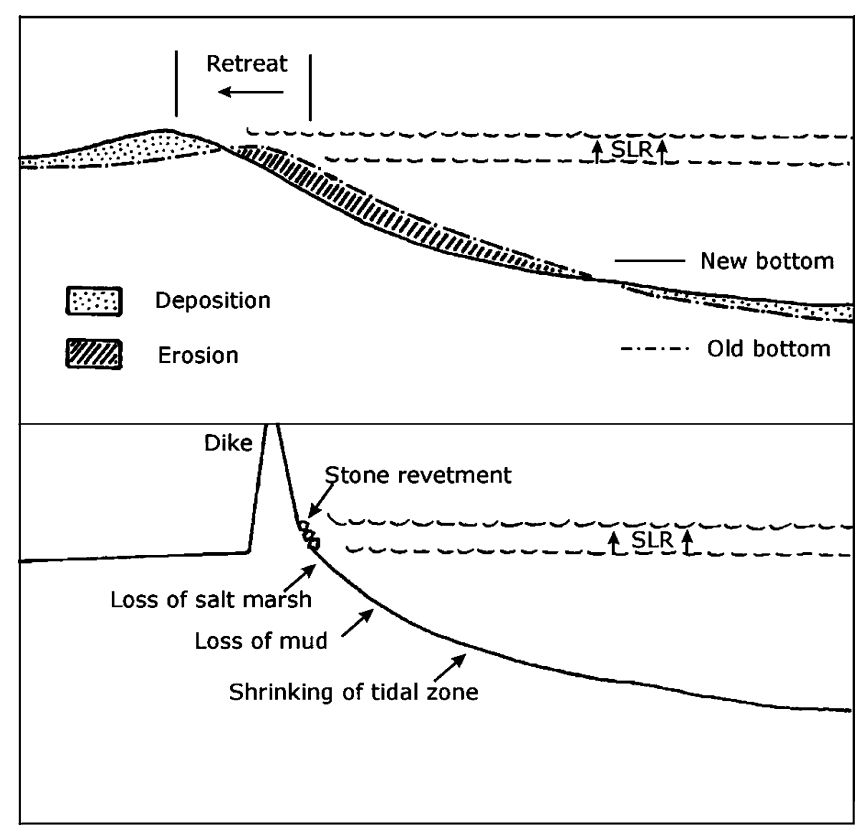

Fig. 5 Effects of sea level rise (SLR) on soft tidal shores lacking an external sediment supply. Above: when undefended, shoreline retreat is associated with sediment redistributions to build a new berm at high water level and to raise the surface of the tidal flats. Below: when provided with a dike to prevent flooding and ersosion, sediment hunger arising from SLR is directed downshore and offshore by stone revetments 
developmental spiral is irreversible as long as sea level is rising. It can only be mitigated by shifting dikes inland or by artificial sediment supplies taken from an external source. Hard structural defences merely transfer the hunger for sediment downshore and thus constitute no sustainable solution.

Barrier islands may absorb most of an external sediment supply or may partly serve as a source of sediment for the back-barrier zone. A size reduction in tidal area by embankments causes a corresponding reduction in the sediment volume of ebb tidal deltas. Part of this volume is needed to adjust tidal basins to sea level rise, while the remainder may contribute to the development of island dunes and high sandy shoals. On the other hand, a decrease in the size of ebb tidal deltas entails erosion of islands in a downstream direction because less wave energy is dissipated. In such cases, islands have been defended with revetments or artificial beach recharge (CPSL 2001).

\section{Embankments and reclamations at the mainland}

A physical, ecological and societal regime shift occurred in the Wadden Sea once a coherent line of earthen sea walls prevented flooding of the marsh. A rigid separation was achieved between land and sea. Diking began slowly after $1000 \mathrm{AD}$ with small, isolated polders, which finally coalesced into a coherent "Golden Ring" between 1200 and 1300 AD (Kramer and Rohde 1992; Wolff 1992b). In a first phase, existing salt marsh pastures were embanked. After $1200 \mathrm{AD}$, this defensive strategy gradually moved on to foster mud accretion seaward of the dikes to gain new salt marsh area which then in turn could be embanked. One polder was created in front of the other, extending the outer dikeline into the tidal area (Fig. 6; Bantelmann 1966; Behre 1999; Prange 1986).

At the same time, peatland in front of pleistocene elevations was reclaimed and pumped dry. This caused bio-oxidation and compaction of the peaty soil. Peat layers were excavated, dried and then burnt. Peat was also mined where it occurred underneath a layer of marine clay. After burning, the salt was extracted for trading. Diked areas had to be drained because of heavy precipitation on an almost impermeable clay or on peaty soil which retained the water. The result of draining and peat mining was an overall subsidence by $2-5 \mathrm{~m}$ at former mires, which thus came to be lower than the surface of new polders closer to the sea, resulting in an inverted wedge-shaped coastal plain.

This vulnerable configuration contributed to the formation of large coastal inlets when dikes were breached during storm surges: Zuiderzee, Middelzee, Lauwerszee and Harlebucht formed between 1000 and 1200 AD (Behre 1999; Oost 1995; Oost and de Boer 1994; Flemming and Davis 1994). Later, more coastal inlets formed or were enlarged in the course of storm tides (Bantelmann 1966; Behre 1999; Prange 1986): Jadebusen in 1164, 1334, 1362 and 1511, Dollard in 1287,
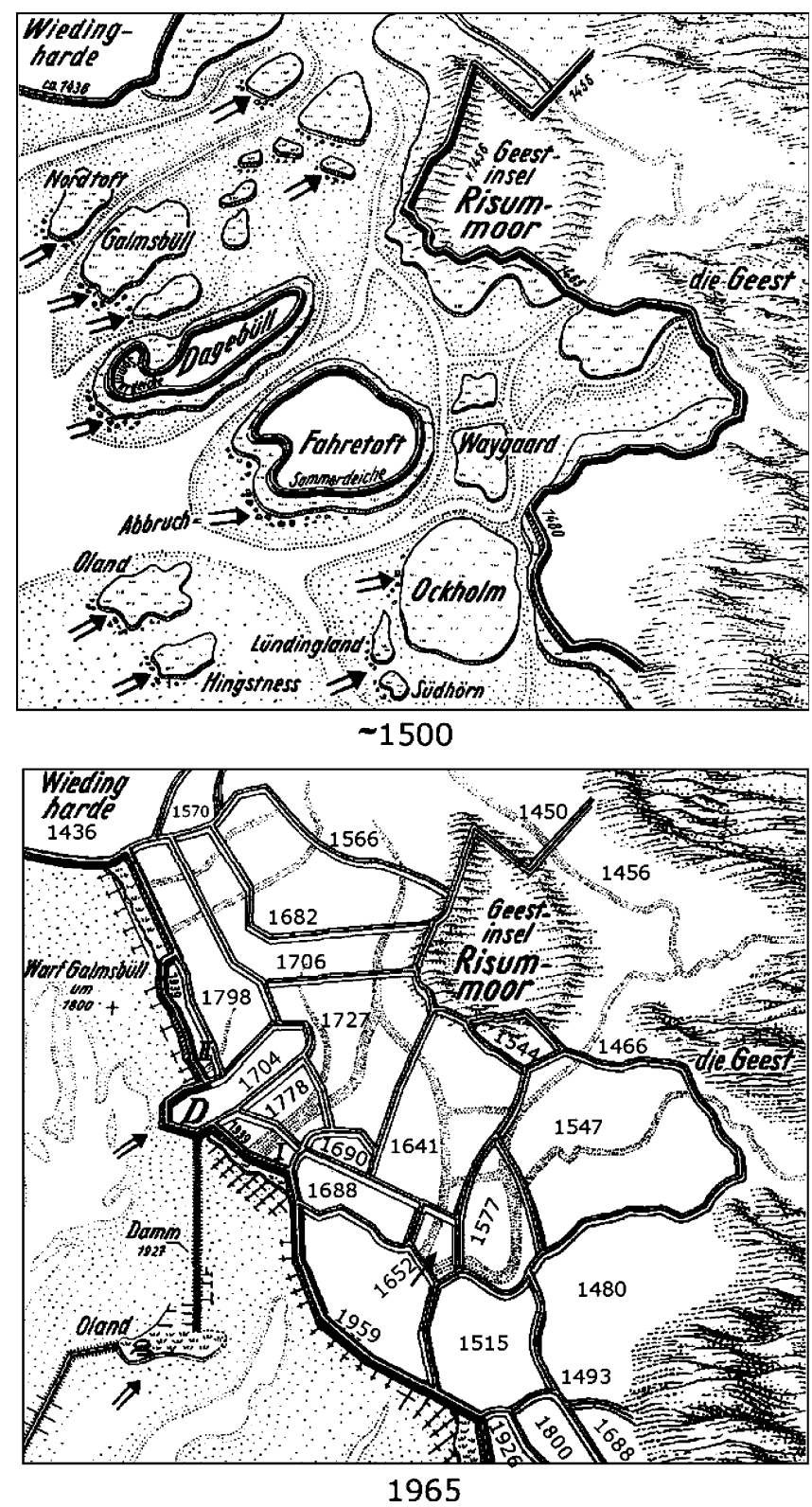

Fig. 6 Progressive re-embankment following medieval storm surges at $20 \mathrm{~km}$ of coastal length in Nordfriesland with Dagebüll $(D)$ and Fahretoft islands in the middle surrounded by low summerdikes in 1500. Pleistocene elevations (Geest) are hatched, salt marshes stippled, tidal flats dotted, former creeks narrowly dotted. Years of diking are indicated. A causeway for lorries to the island of Oland was first built in 1899 and renewed in 1927. Arrows point to sites of shore erosion. Modified from Bantelmann (1966) with data from Prange (1986). After 1965 only $1 \mathrm{~km}^{2}$ of foreland became embanked when reinforcing of the outer dikeline

1362 and 1509, Leybucht in 1219, 1362 and 1374, Nordfriesland in $\sim 1250,1338,1354$ and 1362. Marsh islands such as Bant and Strand became inundated and eroded away. In all these cases man-made subsidence aggravated the effects of flooding.

The eroded material was deposited elsewhere along the coast where embankments started anew. During an exceptional storm surge in 1634, the last major losses of 
Table 2 Large areas separated from the Wadden Sea and converted to land or lakes in the 20th century

\begin{tabular}{lll}
\hline Area & Year & $\mathrm{km}^{2}$ \\
\hline Zuiderzee & 1932 & 3,600 \\
Lauwerszee & 1969 & 90 \\
Lower Elbe & $1969-1979$ & 150 \\
Meldorfer Bucht & $1973-1978$ & 48 \\
Nordstrander Bucht & 1987 & 33 \\
\hline
\end{tabular}

land occurred. Dike building technology has improved since then, and land reclamation works in front of existing dikes have been intensified (Esselink 2000; Kramer and Rohde 1992). The outer dikeline was shifted stepwise seaward and the shore became straight (Table 2; Fig. 6). In the west, the large brackish coastal inlets, Zuiderzee and Lauwerszee, had been cut off in 1932 and 1969, respectively. In Lower Saxony, several small embayments became embanked, while two larger coastal inlets remained open (Dollard and Jadebusen). Both the lower Weser and Elbe became narrower by successive embankments. The Dithmarschen coast has been accretional and here the outer dikeline moved seaward by about $14 \mathrm{~km}$ on average. The Eider estuary became protected by a storm surge barrier in 1972, and has been narrowed by embankments. In Nordfriesland, about half of the previously lost marsh became reembanked until today. A few undiked marsh islands (Halligen) remain scattered over the tidal area. Causeways have been built to the islands of Sylt (1927) and Rømø (1949), separating the List tidal basin from adjacent ones. In the Danish Wadden Sea, diking was mainly defensive, confined to existing salt marshes, except for the Vidå estuary which has been embanked completely.
The net result of this long history of successive embankments and land reclamations is a strict and straight separation between land and sea. Almost all of the episodically flooded marsh, many embayments and brackish areas have been transformed into land or lakes. The Wadden Sea area became reduced to nearly half of its primordial size.

\section{Saltmarsh works}

Compared to pristine salt marshes at the mainland coast, modern ones are small, fragmented, truncated at the landward side, artificially created and of a simplified structure (Fig. 7). The present saltmarsh area of $200 \mathrm{~km}^{2}$ along the mainland, is probably only one-tenth of primordial saltmarsh size. The exact area salt marshes once covered is uncertain because of the gradual transition and intricate mosaic with brackish reed marshes and limnic mires in former times.

Saltmarsh works in front of mainland dikes have replaced almost all natural saltmarsh development (Dijkema 1987; Esselink 2000; Probst 1996). Sea walls have stopped any landward extension of salt marshes in response to sea level rise, and have separated salt marshes from their brackish and limnic hinterland. The habitat for brackish water organisms has been eliminated in the marsh (Michaelis et al. 1992).

Artificial forelands dissipate wave energy and thus protect dikes. Since the 1960s, this became the primary function and rational for continued saltmarsh works. Without this activity, many salt marshes would erode away. Natural saltmarsh development is limited to a few sheltered embayments (i.e. Jadebusen, Leybucht) and to islands where dune development provides new shelter
Fig. 7 Morphology of a natural salt marsh (left) and a reclamation field to create a foreland fronting a dike (right). Adopted from Reents (1995) and schematically drawn from aerial photographs

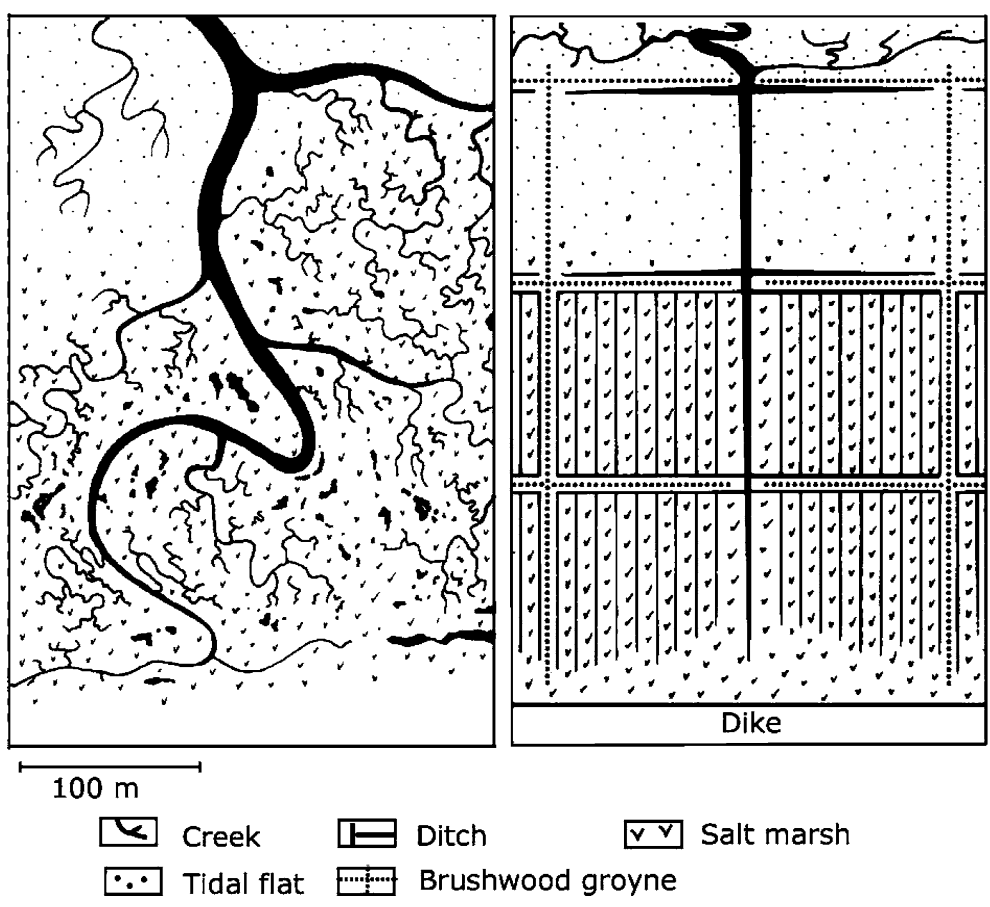


(Dijkema 1987; Bunje and Ringot 2003). The halophytic vegetation is similar between natural and artificial marshes, while domestic grazing pressure may decrease vegetation height from 0.5 to $0.05 \mathrm{~m}$ and dominance shifts between grasses from Elymus athericus to Puccinellia maritima (Bakker et al. 2003). Recent policies seek a compromise between salt marshes functioning as dikeforeland for coastal defence and salt marshes as natural areas. Artificial draining and lifestock grazing have been reduced (Dijkema et al. 2001; CPSL 2001).

In contrast to American salt marshes, those in the Wadden Sea lacked the tall grasses of the genus Spartina. However, a hybrid originating from a natural cross between $S$. maritima and the introduced American $S$. alterniflora was planted in the 1920s at several sites in the Wadden Sea in order to enhance mud accretion (Reise 1994). The subsequent spread of the new S. anglica conspicuously changed the lower salt marsh vegetation. Where Salicornia stricta and P. maritima once dominated, this cordgrass took over to form a coherent belt. Tussocks often grow as pioneers far seaward in the upper tidal zone. S. anglica is now the major pioneer plant of many salt marshes in the Wadden Sea providing a new habitat type.

\section{Habitat changes in the tidal area}

A consequence of an increasing sea level and a smaller flood plain is a steeper slope in bottom topography (Figs. 3, 5). The closure of coastal inlets such as Zuiderzee and Lauwerszee, partial closure of the Eider estuary, size reductions of Dollard, Leybucht, Jadebusen, Meldorfer Bucht and Nordfriesland tidal area, as well as embankments elsewhere along the coast, shortened the distance between barrier islands and mainland. After closure of the Zuiderzee, the tidal range in the Marsdiep tidal basin increased up to $0.5 \mathrm{~m}$ (De Jonge et al. 1993). Generally, high water levels went up while low water levels hardly changed. A shortened width, steeper slope and higher high water levels enhanced hydrodynamics. Therefore, exemplified at the East Frisian coast, the amount of fine particle deposition is decreasing and muddy sediments are losing ground (Dellwig et al. 2000; Flemming and Nyandwi 1994; Flemming and Bartholomä 1997; Mai and Bartholomä 2000). The fining gradient of sediment particle composition became truncated at its landward side by embankments. Embanking muddy coastal inlets and the nearshore mud belt removed fine particles from the sediment budget. Calculations for two tidal basins suggest that the amount of mud lost by land reclamation exceeds the amount still present by a factor of 4-5 (Delafontaine et al. 2000).

More studies are needed to explore the generality of this trend from muddy flats to sandy flats. Where this gradual process occurs, the composition of the benthos is changing from a dominance of mud dwelling surface deposit feeders and diatom grazers to a dominance of sand dwelling subsurface deposit feeders with polychaetes and agile peracarid crustaceans adapted to live in rippled sandy shoals (Lackschewitz and Reise 1998). The List tidal basin behind the islands of Sylt and Rømø lost tidal flat area during the last century. Profiles adopted a concave shape with a steep upper slope and a gentle tapering towards low tide line (Reise 1998). In such a case, species of the nearshore zone become squeezed out.

Subtidal seagrass beds never recovered from a wasting phenomenon in 1932-1934 which affected seagrass beds all along northern Atlantic coasts (Den Hartog 1987; Vergeer et al. 1995). At the two sites with recorded subtidal beds, large scale damming happened concurrently (Hindenburgdamm at Sylt in 1927; Afsluitdijk at Zuiderzee in 1932), which may have contributed to a lack of recovery. Increased turbidity or sediment mobility adjacent to the dams could have been the causal mechanisms. Intertidal seagrass beds declined in the southern and central Wadden Sea between the 1970s and the early 1990s (De Jonge et al. 1993; Kastler and Michaelis 1999; Philippart and Dijkema 1995). Eutrophication has been suggested as a main driver (Philippart 1995; van Katwijk et al. 1999). Increasing turbulence is harmful, too, and may aggravate eutrophication effects (van Katwijk and Hermus 2000; Schanz and Asmus 2003; Schanz et al. 2002).

Overharvesting of natural oyster beds in the Wadden Sea commenced in the 19th century when railways offered swift transports of oysters to distant inland markets (Möbius 1877). The same happened to the vast oyster beds offshore in the North Sea. The final demise of profitable beds occurred in the 1920s, and the Wadden Sea population of $O$. edulis became extinct in the 1950s (Reise et al. 1989). At about that time, Sabellariareefs were systematically destroyed with heavy anchor chains because these reefs interfered with bottom trawling for shrimp (Reise and Schubert 1987).

Mussel fishing proliferated in the 1940s, and subtidal bottom cultures were established since the 1950s (Fig. 3). The area reserved for cultures comprises about $100 \mathrm{~km}^{2}$ (De Jong et al. 1999). Plots with wild beds and former oyster beds were raked free of epibenthos and shell gravel. Then seed mussels dredged from wild beds were spread on the plots (Dankers and Zuidema 1995). In the Dutch Wadden Sea, wild and cultured mussel stocks are of similar size, and presumably the total population has been increased by the cultures. On the other hand, regular harvesting and managing of culture plots is detrimental to most associated organisms, including birds feeding on mussels (Beukema and Cadée 1996; Camphuysen et al. 2002).

Mussel cultures and the loss of seagrass beds, oysters and Sabellaria-reefs have together caused a conspicuous habitat change in the subtidal zone (Fig. 3; Lotze 2005). Comparisons of the subtidal occurrence of epibenthos between the 1920-1930s and the 1980-1990s revealed a decline of sessile species abundances (Buhs and Reise 1997; Reise et al. 1989; Reise and Buhs 1999). It has been 
suggested that intensive bottom trawling for shrimp also contributed to this decline. Recently, a new habitatforming oyster (Crassostrea gigas) has been introduced and is spreading throughout the Wadden Sea (Dankers et al. 2004; Diederich et al., unpublished data). These Pacific oysters are about to take over on intertidal mussel beds and also gradually colonise ambient sediment and subtidal bottoms. The emerging reefs will constitute a new type of habitat in the Wadden Sea.

\section{Lost and converted estuaries}

Except for Varde $\AA$ in the north, all of the many small estuaries have been replaced by sluices or barred against storm surges. Still open but heavily modified are the three large estuaries of Elbe, Weser and Ems. Although the transformations in the mainland marsh and tidal areas described above also apply to estuaries, these are a special case (Kausch 1996; Schirmer 1994; Schuchardt et al. 1999). Major ports in upstream position have prompted the conversion of inner estuaries into deep shipping canals lined by groynes and sidewalls to accommodate the ever larger vessels (Table 3). The largest amounts of dredged sediments are taken from the shipping lanes in the Ems, Jade and Elbe (De Jong et al. 1999). Most of the material is removed from harbours and inner estuaries and dumped in outer estuarine sections with deleterious effects on the benthos. This dredging commenced at the mid-19th century. The depth of the Elbe estuary has been dredged from 4 to $14 \mathrm{~m}$ and the Weser from 3 to $9 \mathrm{~m}$ and $12 \mathrm{~m}$ in the outer part. This is a threefold increase in depth. As a consequence, the tidal flow accelerated. At Hamburg, the tidal range increased from 1.8 to $3.5 \mathrm{~m}$, and at Bremen from 0.3 to $4.1 \mathrm{~m}$ during the last century. While higher high waters require higher dikes, lower low waters caused a more effective draining of sidearms and adjacent marshes. The enhanced currents, together with wave action from the passing vessels, are aggrevating erosion along the banks. To prevent this, shores have been petrified; about $60 \%$ in the Weser between Bremen and Bremerhaven . Upstream weirs prevent riverine sediment flux into the estuary, while the deepened canals trigger sediment imports from the North Sea. Continuous dredging is re-

Table 3 Areal decrease of habitats in the 20th century in the Elbe estuary between Hamburg and Cuxhaven (from data in Schirmer 1994). Note that the intertidal area decreased in spite of an increase in tidal range, indicating the growing steepness of the slope towards the deep shipping lane

\begin{tabular}{|c|c|c|c|}
\hline \multirow[t]{2}{*}{ Habitats } & \multicolumn{3}{|c|}{ Habitats $\left(\mathrm{Km}^{2}\right)$} \\
\hline & $1896-1905$ & $1981-1982$ & Loss $\%$ \\
\hline $\begin{array}{l}\text { Foreland between } \\
\text { dike and river (marsh) }\end{array}$ & 214.3 & 72.7 & 66 \\
\hline Intertidal flats & 216.7 & 192.9 & 11 \\
\hline $\begin{array}{l}\text { Shallow subtidal between } \\
\text { mean low tide and }-2 \mathrm{~m}\end{array}$ & 78.2 & 57.7 & 26 \\
\hline
\end{tabular}

quired to maintain the desired depths. Submersed vegetation is mostly gone. The loss of sidearms diminished the fauna. However, as pointed out by Witt (2004) for the Weser estuary, in spite of a low point diversity the total number of benthic species is still rather high. This is explained by the salinity gradient plus a variety of substrates at various depth zones which together amount to a high habitat diversity. Nevertheless, most of the former filtering and retention capacity of the estuaries is lost. The deep canals flush riverine loads right through into the North Sea.

\section{Wadden islands and adjacent offshore areas}

Uninhabited small islands and sand bars still undergo considerable changes in size and shape (Bunje and Ringot 2003; Ehlers 1988; CPSL 2001). This was also the case with larger islands. Villages often had to be given up and were then rebuilt at new locations. Since the last century, however, attempts to fix island positions against natural dynamics have become the rule. In the long run, this strategy may exceed the costs of moving or rebuilding infrastructures. Dunes were occasionally breached by storm surges. This gave rise to complex habitat successions. However, in most cases gaps were artificially closed to stabilise the situation. Also, almost all mobile dunes have been planted with marram grass (Ammophila arenaria) for stabilisation.

Dune islands were scarcely populated until a massive tourist invasion in the 20th century. Since then, beach or cliff erosion has been partly stopped by hard defences, i.e., stone walls, revetments and groynes at Texel, Vlieland, Borkum, Norderney, Baltrum, Spiekeroog, Wangerooge, Amrum, Sylt and Skallingen peninsula. In the last two decades, regular sand replenishments have been employed to compensate losses at the beach. Marsh islands in the northern Wadden Sea have been diked or protected by stone revetments against the prevailing erosion. The situation is unstable and requires intensive maintenance.

The shallow bottoms seaward of barrier islands are subject to disturbance by towed bottom fishing gears, aiming primarily at flatfish, shrimp and shellfish. Lasting effects on the habitat are probably subtle because of the high natural dynamics of these sandy shallow bottoms close to the coast (Kaiser et al. 2003). Sand extractions for beach nourishment are taken at specified sites within a few kilometres offshore, and in the Dutch part from below a depth of $-20 \mathrm{~m}$. The overall habitat disturbance by human activities in this zone adjacent to the barrier islands may be still regarded as low at least until now. This may change with the prospect of wind energy farms next to this nearshore zone.

An introduced habitat: artificial hard substrates

The primordial Wadden Sea was free of rock. There are only a few boulders and some shingle where pleistocene 
deposits came under erosion (i.e., at cliffs of Föhr, Sylt, Emmerlev Klit and at great depths in estuaries and tidal inlets). This scarcity of hard substrates changed with the beginning of coastal defence and harbour piers. These were wooden structures in earlier times, but, since the 20 th century, breakwaters, groynes, revetments, sea walls and harbour walls are built primarily out of stone or concrete. Occasionally, iron or other materials are employed as buoys, ships, groynes and piers. The fouling biota generally resemble those of natural rocky shores and biogenic reefs (Buschbaum 2000; Luther 1976; Witt 2004).

As a rough estimate, the approximate length of petrified shorelines below mean high tide is about $730 \mathrm{~km}$ (based on maps in Dijkema et al. 1989; and own unpublished data). Multiplied by an average width of 3$5 \mathrm{~m}$, an artificial reef area of $2-4 \mathrm{~km}^{2}$ of hard bottoms may be assumed, stretching almost continuously through the entire Wadden Sea. With increasing hydrodynamics and shore erosion in the tidal basins of the Wadden Sea in the wake of sea level rise and with more infrastructures, these artificial hard substrates are expected to propagate. They account for the widespread occurrence of species otherwise rare or absent in a sedimentary environment, ranging from the isopod Ligia oceanica in the supratidal to the kelp Laminaria saccharina in the subtidal zone.

\section{Syndromatic coastal degradation}

The term syndrome is here used in anology to medicine as a typical cluster of symptoms indicating an evident misdevelopment or problematic people-environment interaction (Schellnhuber et al. 1997; Lüdeke et al. 2004), applied by Meybeck (2003) to rivers and in this paper to a coastal region. In the Wadden Sea, the disposition factor is a low-lying coastal area rich in resources and readily accessible from land and sea. Therefore this region was populated since it came into existence, and has been increasingly converted to human needs since the last 1,000 years. The kernel of the underlying functional pattern of the Wadden Sea syndrome is the growing discrepancy between the rising level of the sea and the position of an artificially fixed and defended shoreline. A trajectory of non-sustainable coastal development results from attempts to hold the line in the face of rapid sea level rise (Charlier 2003). Coastal defence structures have to be strengthened and natural habitats between land and sea become squeezed out or deteriorate. In estuaries, this is exacerbated by the maintenance of deep shipping canals. Embedded in these grand processes are the effects of fisheries, introduced species, eutrophication and pollution, all contributing to a decline or change in coastal habitat diversity. The process of relative sea level rise has anthropogenic components in itself, locally and regionally in the modified coastal shape and man-made subsidence, globally in greenhouse gas emissions which warm atmosphere and oceans, and may cause higher storm surge probabilities.

The syndrome gradually came into existence as sea level has risen, as the surface level of reclaimed land has gone down, and with a dikeline that was moved further into the sea. It may soon enter a critical and malignant stage, and has locked coastal management into a spiral of increasing investments for coastal defence, the coastal inhabitants into increasing risks from storm surges, while recreational value, richness of living resources and habitat diversity are in decline.

The nine major symptoms of modern coastal architecture are:

1. Inverted coastal wedge: ongoing subsidence of embanked and reclaimed marsh surfaces caused by drainage and soil compaction, with the oldest marsh sinking below sea level, locally aggravated by former peat mining and recent gas extraction. This entails a risk for inhabitants of the old marsh and requires highly reliable sea defences.

2. Impermeable dikeline: with a few exceptions, sluices let freshwater out but no seawater in. Together with dikes, this effectively eliminates brackish transitional habitats and blocks migrations of aquatic organisms between marine and limnic waters.

3. Straight outer dikeline: this is dictated by cost efficiency and eliminates sheltered embayments in which salt marsh development by natural accretion could proceed.

4. Foreland displaces natural saltmarsh development: artificially created and maintained dike forelands of simplified structure tend to be narrow and are isolated from brackish and limnic habitats as well as from other saltmarsh areas.

5. Sprawl of hard coastal defences: revetments and groynes to stop shore erosion do not mitigate sediment deficiency caused by sea level rise, but initiate downstream erosion at undefended shores. The artificial rock habitat often replaces an upper sequence of sedimentary habitats.

6. Storm surge barriers: prevent flooding of estuarine habitats during extreme high water levels and thus delimit space for storm flood waters in the fronting embayments. This discloses the marsh from deposits to rise with sea level and outside the barrier habitat erosion is accelerated.

7. Estuarine conversion into shipping canals: this requires continuous dredging and causes increased sediment mobility, increased tidal range and current speeds. This entails more shore erosion and a lack of slackwater habitats at sidearms. Riverine loads are flushed right through.

8. Land reclamation, embankments and damming have delimited the tidal area, increased storm surge levels and hydrodynamic energy input per unit area resulting in a loss of fine particulate mud flats.

9. Island stabilisations prevent islands from adjusting their position to changing sea level and sediment 
supply. Hard defence structures and continuous sand recharges are employed.

These symptoms of the anthropogenic coastal architecture are interlinked and may interact with other anthropogenic changes in the Wadden Sea. Effects of pollution and eutrophication are partly aggravated by the lack of extensive coastal and riverine marshes acting as filter and retention areas for allochthonous substances. On the other hand, these substances are now flushed through a simplified and a hydrographically more dynamic coastal zone. The effects are diverted to other regions downstream. The global dissemination of allochthonous coastal species has resulted in the introduction of the cordgrass $S$. anglica and the Pacific oyster C. gigas, both of which have established new habitat types displacing native ones. The former may extend salt marshes, and reefs of the latter may stabilise sediments to some extent. The coastal fishery has removed highdiversity habitats (oyster beds and Sabellaria-reefs), and added low-diversity mussel culture plots. Besides many local deviations from general trends and some compensating processes, a spiral of habitat loss and degradation has been the prevailing course of change in historical time.

\section{Conclusions and perspectives}

This historical approach highlights that massive interventions in the Wadden Sea coastal system over the last 1,000 years have increasingly distracted coastal morphology and habitats from their functions to dissipate energy from waves and tides, to retain imports of deposits and substances, and to provide enough space and dynamic heterogeneity for the persistence of biodiversity (Fig. 5). The intensity of change has been highest in the marsh and estuaries, moderate in the tidal area and relatively minor on the barrier islands. The offshore area is the least modified, but will probably have to accommodate wind energy farms in the near future.

Human effects on extent, diversity and composition of habitats were confined to the marsh until about 1200 AD. Then, major storm surges enlarged the tidal area by flooding the reclaimed and subsiding land. Most of these losses were subsequently regained (Table 1). Since the mid-17th century, embankments became permanent. During the last century particularly, large tidal areas were embanked or dammed (Table 2), brackish transitions vanished and estuaries were turned into shipping canals (Table 3). Inhabited parts of barrier islands were stabilised. Shoreline petrifications sprawled and habitat dynamics at the upper shore almost ceased. Fisheries and eutrophication contributed to the loss of highdiversity habitats.

The Wadden Sea region not only became physically smaller by the separation of landward habitats from the sea. Confining the trilateral management plan, the biosphere reserves and national parks to that part of the
Wadden Sea which has not yet been strongly modified (i.e., by excluding the large estuaries, the former Zuiderzee, the embanked marshes), is a conceptual retreat to a truncated coastal ecosystem which may not be able to persist or to be maintained in the face of sea level rise.

Over the last three decades the attitude in coastal management has been changing. Most of the tidal area is under nature protection, and the idea of long-term coastal sustainability is literally gaining ground (CPSL 2001). Low summer dikes become perforated to convert pastures back into salt marshes. Land reclamation works proceed only in front of those dikes which lack sufficient foreland. Grazing pressure and drainage has been reduced to restore more natural saltmarsh vegetation. In some reclaimed polders, artificial lagoons are managed to sustain semi-marine conditions. On barrier islands, eroding beaches are recharged with sand taken from offshore, instead of employing more and more hard defences.

However, there is still a long way to go until coastal sustainability can be achieved in a sense, that the ability of future generations to live at and enjoy the coast is not compromised. The recognition of the long temporal scales over which coastal morphodynamics unfold is still in its infancy with regard to coastal policies. The strategy to cope with accelerating sea level rise continues to rely on on-line defences rather than adopting a strategy of coastal realignment as is being attempted in Britain (Burbridge and Pethick 2003; French 2001). In particular, harbour locations and nuclear power plants in estuaries, and urban developments on barrier islands, are still regarded as permanent and to be defended against all risks at all times. On the other hand, there are options worthy of consideration which could develop the Wadden Sea region more into the direction of habitat sustainability:

1. The method of sand replenishments to balance the sediment hunger of sea level rise could be extended to sheltered shores, where lost transitional habitats of the upper shore could be restored with sand deposits in the form of islets, bars and spits (Reise 2003; Reise and Lackschewitz 2003).

2. The inverted wedge-shaped profile of the embanked marsh could be employed to convert polders which are below mean sea level into reservoirs for flood waters during storm surges by using sluices and drainage canals in reversed direction (Reise 1996). Where necessary, houses have to be placed upon mounds as was practised before diking. Such reservoirs could alleviate pressure on the outer dikeline, and also improve the touristic reputation of the marsh.

3. Estuaries are bound to function as shipping canals with ever greater depth as long as ports remain in upstream positions. Shifting harbour facilities to a central platform in the North Sea from where small feeder ships commute to ports along rivers could allow estuaries to regain former retention properties and habitat diversity. These options need to be ad- 
dressed by interdisciplinary research to find costeffective solutions with multiple benefits, and to be developed together with stakeholders. The coastal syndrome diagnosed above may be viewed on a global scale. Similar coastal wetland degradations have occurred elsewhere in Europe and overseas, and all are subject to continued sea level rise with a limited potential for natural transgressions to unfold. The habitat history of the Wadden Sea offers lessons which could help to avoid repeating failures of the past. Concerning the habitat history of the Wadden Sea, there are still gaps in knowledge which in particular could benefit from paleoecological research and attempts to model habitat proportions.

Acknowledgements Heike Lotze, Norbert Dankers and Justus van Beusekom made valuable suggestions on the manuscript. I thank Lilo Herre for help with the figures.

\section{References}

Abrahamse J (1976) Waddenzee, natuurgebied van nederland, duitsland en denemarken. Landelijke vereniging tot behoud van de waddenzee. Harlingen, The Netherlands

Anonymous (1991) The Wadden Sea: Status and developments in an international perspective. Report to the 6th trilateral governmental conference on the protection of the Wadden Sea in Esbjerg. National Forest and Nature Agency, the Ministry of the Environment, Denmark and the Common Wadden Sea Secretariat, Wilhelmshaven

Anonymous (2001) Generalplan Küstenschutz. Integriertes Küstenschutzmanagement in Schleswig-Holstein. Ministerium für ländliche Räume, Landesplanung, Landwirtschaft und Tourismus des Landes Schleswig-Holstein, Kiel

Bakker JP, Bos D, de Vries Y (2003) To graze or not to graze: that is the question. In: Wolff WJ, Essink K, Kellermann A, van Leeuwe MA (eds) Challenges to the Wadden Sea. Proceedings of the 10th international scientific Wadden Sea symposium. Ministry of Agriculture, Groningen, The Netherlands, pp 67-87

Bantelmann A (1966) Die Landschaftsentwicklung an der schleswig-holsteinischen Westküste, dargestellt am Beispiel Nordfriesland. Die Küste 14(2):5-99

Behre KE (1999) Die Veränderung der niedersächischen Küstenlinien in den letzten 3000 Jahren und ihre Ursachen. Probleme der Küstenforschung im südlichen Nordseegebiet 26:9-33

Behre KE (2001) Holozäne Küstenentwicklung, Meeresspiegelbewegungen und Siedlungsgeschehen an der südlichen Nordsee. Bamberger Geogr Schr 20:1-18

Behre KE (2002) Landscape development and occupation history along the southern North Sea coast. In: Wefer G, Berger W, Behre KE, Jansen E (eds) Climate development and history of the North Atlantic realm. Springer, Berlin Heidelberg New York, pp 299-312

Beukema JJ, Cadée GC (1996) Consequences of the sudden removal of nearly all mussels and cockles from the Dutch Wadden Sea. P.S.Z.N. I: Mar Ecol 17:279-289

Buhs F, Reise K (1997) Epibenthic fauna dredged from tidal channels in the Wadden Sea of Schleswig-Holstein: spatial patterns and a long-term decline. Helgol Meeresunters 51:343-359

Bunje J, Ringot JL (2003) Lebensräume im Wandel. Flächenbilanz von Salzwiesen und Dünen im niedersächischen Wattenmeer zwischen den Jahren 1966 und 1997. Schriftenreihe Nationalpark Niedersächsisches Wattenmeer, Wilhelmshaven 7:1-48

Burbridge PR, Pethick J (2003) Sustainability and management: coastal systems. In: Wefer G, Lamy F, Mantoura F (eds)
Marine science frontiers of Europe. Springer, Berlin Heidelberg New York, pp 217-228

Buschbaum C (2000) Siedlungsmuster und Wechselbeziehungen von Seepocken (Cirripedia) on mussel beds (Mytilus edulis L.) in the Wadden Sea. Ber Polar-Meeresforsch, Alfred-WegenerInstitut für Polar- und Meeresforschungen 408, Bremerhaven

Camphuysen CJ, Berrevoets CM, Cremers HJWM, Dekinga A, Dekker R, Ens BJ, van der Have TM, Kats RKH, Kuiken T, Leopold MF, van der Meer J, Piersma T (2002) Mass mortality of common eiders (Somateria mollissima) in the Dutch Wadden Sea, winter 1999/2000: starvation in a commercially exploited wetland of international importance. Biol Conserv 106:303-317

Charlier RH (2003) Hold the sea back - is it sustainable? Retrospective and projection. J Coast Res 19:875-883

CPSL (2001) Final report of the trilateral working group on coastal protection and sea level rise. Wadden Sea ecosystem 13. Common Wadden Sea Secretariat, Wilhelmshaven, Germany

Dankers N, Zuidema DR (1995) The role of the mussel (Mytilus edulis L.) and mussel culture in the Dutch Wadden Sea. Estuaries $18: 71-80$

Dankers NMJA, Dijkman EM, de Jong ML, de Kort G, Meijboom A (2004) De verspreiding en uitbreiding van de Japanse Oester in der Nederlands Waddenzee. Wageningen, Alterra-rapport 909

De Jong F, Bakker JF, Dahl K, Dankers N, Farke H, Jäppelt W, Koßmagk-Stephan K, Madsen PB (1993) Quality status report of the North Sea, Subregion 10 The Wadden Sea. Common Wadden Sea Secretariat, Wilhelmshaven, Germany

De Jong F, Bakker JF, van Berkel CJM, Dahl K, Dankers NMJA, Gätje C, Marencic H, Potel P (1999) Wadden Sea quality status report. Wadden Sea ecosystem 9. Common Wadden Sea Secretariat, Wilhelmshaven, Germany

De Jonge VN, de Jong DJ (1992) Role of tide, light and fisheries in the decline of Zostera marina L., in the Dutch Wadden Sea. Neth Inst Sea Res Publ Ser 20:161-176

De Jonge VN, Essink K, Boddeke R (1993) The Dutch Wadden Sea: a changed ecosystem. Hydrobiologia 265:45-71

Delafontaine MT, Flemming BW, Mai S (2000) The Wadden Sea squeeze as a cause of decreasing sedimentary organic loading. In: Flemming BW, Delafontaine MT, Liebezeit G (eds) Muddy coast dynamics and resource management. Elsevier, Amsterdam, pp 273-286

Dellwig O, Hinrichs J, Hild A, Brumsack H-J (2000) Changing sedimentation in tidal flat sediments of the southern North Sea from the Holocene to the present: a geochemical approach. J Sea Res 44:195-208

Den Hartog C (1987) "Wasting disease" and other dynamic phenomena in Zostera beds. Aquat Bot 27:3-14

Dijkema KS (1983) Flora and vegetation of the Wadden Sea islands and coastal areas. Appendix: landscape \& vegetation maps. In: Wolff WJ (ed) Ecology of the Wadden Sea. Balkema, Rotterdam

Dijkema KS (1987) Changes in salt-marsh area in the Netherlands Wadden Sea after 1600. In: Huiskes AHL, Blom CWPM, Rozema J (eds) Vegetation between land and sea. Junk, Dordrecht, The Netherlands, pp 42-49

Dijkema KS (1991) Towards a habitat map of The Netherlands, German and Danish Wadden Sea. Ocean Shoreline Manage $16: 1-21$

Dijkema KS, van Tienen G, van Beek JG (1989) Habitats of the Netherlands, German and Danish Wadden Sea. Res Inst Nature Management, Texel. Veth Foundation, Leiden

Dijkema KS, Nicolai A, de Vlas J, Smit C, Jongerius H, Nauta H (2001) Van landaanwinning naar kwelderwerken. Rijkswaterstaat directie Noord-Nederland, Leeuwarden, The Netherlands

Ehlers J (1988) The morphodynamics of the Wadden Sea. Balkema, Rotterdam

Esselink P (2000) Nature management of coastal salt marshes. Interactions between anthropogenic influences and natural dynamics. Koeman en Bijkerk, Haren, The Netherlands

Flemming BW (2002) Effects of climate and human interventions on the evolution of the Wadden Sea depositional system 
(southern North Sea). In: Wefer G, Berger W, Behre KE, Jansen E (eds) Climate development and history of the North Atlantic realm. Springer, Berlin Heidelberg New York, pp 399413

Flemming BW, Bartholomä A (1997) Response of the Wadden Sea to a rising sea level: a predictive empirical model. Dt Hydrogr Z 49:343-353

Flemming BW, Davis RA (1994) Holocene evolution, morphodynamics and sedimentology of the Spiekeroog barrier island system (southern North Sea). Senckenbergiana Maritima 24:117-155

Flemming BW, Nyandwi N (1994) Land reclamation as a cause of fine-grained sediment depletion in backbarrier tidal flats (southern North Sea). Neth J Aquat Ecol 28:299-307

French PW (2001) Coastal defences: processes, problems and solutions. Routledge, London

Hagmeier A, Kändler R (1927) Neue Untersuchungen im nordfriesischen Wattenmeer und auf den fiskalischen Austernbänken. Wiss Meeresunters (Abt Helgoland) 16:1-90

Hertweck G, Liebezeit G (2002) Historic mussel beds (Mytilus edulis) in the sedimentary record of a back-barrier tidal flat near Spiekeroog Island, southern North Sea. Helgol Mar Res 56:5158

IPCC (2001) Climate change. Synthesis. Report. www.ipcc.ch

Jones CG, Lawton JH, Shachak M (1994) Organisms as ecosystem engineers. Oikos 69:373-386

Kaiser MJ, Collie JS, Hall SJ, Poiner IR (2003) Long-term habitat changes and their implications for future fisheries management. In: Wefer G, Lamy F, Mantoura F (eds) Marine Science Frontiers of Europe. Springer, Berlin Heidelberg New York, pp 189-201

Kastler T, Michaelis H (1999) The decline of seagrasses, Zostera marina and Zostera noltii, in the Wadden Sea of Lower Saxony. Senckenbergiana Maritima 29:77-80

Kausch H (1996) Fahrwasservertiefungen ohne Grenzen? In: Lozán JL, Kausch H (eds) Warnsignale aus den Flüssen und Astuaren. Blackwell, Berlin, pp 162-168

Knottnerus O (2001) The Wadden Sea region: a unique cultural landscape. In: Vollmer M, Guldberg M, Maluck M, Marrewijk D, Schlicksbier G (eds) Landscape and cultural heritage in the Wadden Sea region. Wadden Sea ecosystem 12. Common Wadden Sea Secretariat. Wilhelmshaven, Germany, pp 12-71

Kramer J, Rohde H (eds) (1992) Historischer Küstenschutz. Konrad Wittwer, Stuttgart

Lackschewitz D, Reise K (1998) Macrofauna on flood delta shoals in the Wadden Sea with an underground association between the lugworm Arenicola marina and the amphipod Urothoe poseidonis. Helgol Meeresunters 52:147-158

Linke O (1939) Die Biota des Jadebusenwattes. Helgol Wiss Meeresunters 1:201-348

Lotze HK (2005) Radical changes in the Wadden Sea fauna and flora over the last millenium. Helgol Mar Res (this volume)

Louters T, Gerritsen F (1994) The riddle of the sands. A tidal system's answer to a rising sea level. Report RIKZ-94.040. RIKZ, Den Haag

Lüdeke MKB, Petschel-Held G, Schellnhuber HJ (2004) Syndromes of global change: the first panoramic view. Gaia 13:4249

Luther G (1976) Bewuchsuntersuchungen auf Natursteinsubstraten im Gezeitenbereich des Nordsylter Wattenmeeres. Helgol Wiss Meeresunters 28:145-166

Mai S, Bartholomä A (2000) The missing mud flats of the Wadden Sea: a reconstruction of sediments and accommodation space lost in the wake of land reclamation. In: Flemming BW, Delafontaine MT, Liebezeit G (eds) Muddy coast dynamics and resource management. Elsevier, Amsterdam, pp 257-272

Meybeck M (2003) Global analysis of river systems: from earth system controls to anthropocene syndromes. Phil Trans R Soc Lond B, DOI 10.1098/rstb.2003.1379

Michaelis H, Fock H, Grotjahn M, Post D (1992) The status of the intertidal zoobenthic brackish-water species in estuaries of the German Bight. Neth J Sea Res 30:201-207
Miller L, Douglas BC (2004) Mass and volume contributions to twentieth-century global sea level rise. Nature 428:406-409

Möbius K (1877) Die Auster und die Austernwirthschaft. Wiegandt, Hempel \& Parey, Berlin

Nienburg W (1927) Zur Ökologie und Flora des Wattenmeeres. Der Königshafen bei List auf Sylt. Wiss Meeresunters (Abt Kiel) 20:146-196

Olsen OT (1883) The piscatorial atlas of the North Sea, English and St George's channels. Taylor \& Francis, London

Oost AP (1995) Dynamics and sedimentary development of the Dutch Wadden Sea with emphasis on the Frisian Inlet. A study of the barrier islands, ebbtidal deltas, inlets and drainage basins. University of Utrecht, Utrecht

Oost AP, de Boer PL (1994) Sedimentology and development of barrier islands, ebb-tidal deltas, inlets and backbarrier areas of the Dutch Wadden Sea. Senckenbergiana Maritima 24:65-115

Pethick J (2001) The Anglian Coast. In: Bodungen B von, Turner RK (eds) Science and integrated coastal management. Dahlem University Press, Berlin, pp 121-133

Philippart CJM (1995) Effect of periphyton grazing by Hydrobia ulvae on the growth of Zostera noltii on a tidal flat in the Dutch Wadden Sea. Mar Biol 122:431-437

Philippart CJM, Dijkema KS (1995) Wax and wane of Zostera noltii Hornem. in the Dutch Wadden Sea. Aquat Bot 49:255268

Philippart CJM, Dijkema KS, van der Meer J (1992) Wadden Sea seagrasses: where and why? Neth Inst Sea Res Publ Ser 20:177191

Plath M (1943) Die biologische Bestandsaufnahme als Verfahren zur Kennzeichnung der Wattsedimente und die Kartierung der nordfriesischen Watten. Westküste, Kriegsheft, pp 7-46

Prange W (1986) Die Bedeichungsgeschichte der Marschen in Schleswig-Holstein. Probleme der Küstenforschung im südlichen Nordseegebiet 16:1-53

Probst B (1996) Deichvorlandbewirtschaftung im Wandel der Zeit. Die Küste 58:47-60

Pugh D (2004) Changing sea levels: efefcts of tides, weather and climate. Cambridge University Press, Cambridge

Reents S (1995) Vergleich von Grüppensystemen in den Vorländern der Groninger Festlandküste mit natürlichen Prielsystemen in vier Referenzgebieten. Diplomarbeit CAU Kiel, Germany

Reise K (1994) Das Schlickgras Spartina anglica: die Invasion einer neuen Art. In: Lozán JL, Rachor E, Reise K, Westernhagen H von, Lenz W (eds) Warnsignale aus dem Wattenmeer. Blackwell, Berlin, pp 211-214

Reise K (1996) Das Ökosystem Wattenmeer im Wandel. Geogr Rdschau 48:442-449

Reise K (1998) Coastal change in a tidal backbarrier basin of the northern Wadden Sea: are tidal flats fading away? Senckenbergiana Maritima 29:121-127

Reise K (2003) More sand to the shorelines of the Wadden Sea. Harmonizing coastal defense with habitat dynamics. In: Wefer G, Lamy F, Mantoura F (eds) Marine science frontiers of Europe. Springer, Berlin Heidelberg New York, pp 203-216

Reise K, Buhs F (1999) Reply to the comment of Damm and Neudecker (1999): long-term decline in epibenthic fauna of tidal channels near the island of Sylt in the northern Wadden Sea. Helgol Mar Res 53:143-145

Reise K, Herre E, Sturm M (1989) Historical changes in the benthos of the Wadden Sea around the island of Sylt in the North Sea. Helgol Meeresunters 43:417-433

Reise K, Lackschewitz D (2003) Combating habitat loss at eroding Wadden Sea shores by sand replenishment. In: Wolff WJ, Essink K, Kellermann A, Leeuwe MA van (eds) Challenges to the Wadden Sea. Proceedings of the 10th international scientific Wadden Sea symposium. Ministry of Agriculture, Groningen, The Netherlands, pp 197-206

Reise K, Schubert A (1987) Macrobenthic turnover in the subtidal Wadden Sea: the Norderaue revisited after 60 years. Helgol Meeresunters 41:69-82

Rippon S (2000) The transformation of coastal wetlands. Oxford University Press, Oxford 
Rohde H (1977) Sturmfluthöhen und sekularer Wasseranstieg an der deutschen Nordseeküste. Die Küste 30:52-143

Schanz A, Asmus H (2003) Impact of hydrodynamics on development and morphology of intertidal seagrasses in the Wadden Sea. Mar Ecol Prog Ser 261:123-134

Schanz A, Polte P, Asmus H (2002) Cascading effects of hydrodynamics on an epiphyte-grazer system in intertidal seagrass beds of the Wadden Sea. Mar Biol 141:287-297

Schellnhuber HJ, Block A, Cassel-Gintz M, Kropp J, Lammel G, Lass W, Lienenkamp R, Loose C, Lüdeke MKB, Moldenhauer O, Petschel-Held G, Plöchl M, Reusswig F (1997) Syndromes of global change. Gaia 13:42-49

Schirmer M (1994) Ökologische Konsequenzen des Ausbaus der Ästuare von Elbe und Weser. In: Lozán JL, Rachor E, Reise K, Westernhagen $\mathrm{H}$ von, Lenz W (eds) Warnsignale aus dem Wattenmeer. Blackwell, Berlin, pp 164-171

Schuchardt B, Schirmer M, Janssen G, Nehring S, Leuchs H (1999) Estuaries and brackish waters. In: De Jong F, Bakker JF, van Berkel CJM, Dahl K, Dankers NMJA, Gätje C, Marencic H, Potel P (eds) Wadden Sea quality status report. Wadden Sea ecosystem 9. Common Wadden Sea Secretariat, Wilhelmshaven, Germany, pp 175-186

Ssymank A, Dankers N (1996) Red list of biotopes and biotope complexes of the Wadden Sea. Helgol Meeresunters 50[Suppl]:9-37

Stade Declaration (1998) Trilateral Wadden Sea plan. Ministerial declaration of the 8th trilateral govermental conference on the protection of the Wadden Sea. Common Wadden Sea Secretariat, Wilhelmshaven, Germany

Streif H (1989) Barrier islands, tidal flats, and coastal marshes resulting from a relative rise of sea level in East Frisia on the German North Sea coast. Proceedings of the KNGMG symposium "Coastal Lowlands, Geology and Geotechnology". Kluwer Academic, Dordrecht, pp 213-223

van Eerden MR, Lenselink G, Zijlstra M (1997) Long-term changes in wetland area and composition in the Netherlands affecting the carrying capacity for wintering water birds. Van Zee tot Land (Lelystad) 65:31-56

van Katwijk MM (2003) Reintroduction of eelgrass (Zostera marina L.) in the Dutch Wadden Sea: a research overview and management vision. In: Wolff WJ, Essink K, Kellermann A,
Leeuwe MA van (eds) Challenges to the Wadden Sea. Proceedings of the 10th international scientific Wadden Sea symposium. Ministry of Agriculture, Groningen, The Netherlands, pp 173-195

van Katwijk MM, Hermus DCR (2000) Effects of water dynamics on Zostera marina transplantation experiments in the intertidal Dutch Wadden Sea. Mar Ecol Prog Ser 208:107-118

van Katwijk MM, Schmitz GHW, Gasseling AP, van Avesaath PH (1999) Effects of salinity and nutrient load and their interaction on Zostera marina . Mar Ecol Prog Ser 190:155-165

Vergeer LHT, Arts TL, de Groot JD (1995) The "wasting disease" and the effect of abiotic factors (light intensity, temperature, salinity) and infection with Labyrinthula zosterae on the phenolic content of Zostera marina shoots. Aquat Bot 52:35-44

Wang Y, Zou X, Zhu D (2000) The utilization of coastal tidal flats: a case-study on Integrated Coastal Area Management from China. In: Flemming BW, Delafontaine MT, Liebezeit G (eds) Muddy coast dynamics and resource management. Elsevier, Amsterdam, pp 287-294

Witt J (2004) Analysing bracksih benthic communities of the Weser estuary: spatial distribution, variability and sensitivity of estuarine invertebrates. PhD Thesis, Universität Bremen, Germany

Wohlenberg E (1935) Beobachtungen über das Seegras, Zostera marina L., und seine Erkrankung im nordfriesischen Wattenmeer. Nordelbingen 11:1-19

Wohlenberg E (1937) Die Wattenmeer-Lebensgemeinschaften im Königshafen von Sylt. Helgol Wiss Meeresunters 1:1-92

Wolff WJ (ed) (1983) Ecology of the Wadden Sea. Balkema, Rotterdam

Wolff WJ (1992a) Ecological developments in the Wadden Sea until 1990. Neth Inst Sea Res Publ Ser 20:23-32

Wolff WJ (1992b) The end of a tradition: 1000 years of embankment and reclamation of wetlands in the Netherlands. Ambio $21: 287-291$

Wolff WJ (2005) The impact of exploitation on the living resources of the Dutch Wadden Sea: an historical overview. Helgol Mar Res (this volume)

Wolff WJ, van der Land J, Nienhuis PH, De Wilde PAWJ (1993) The functioning of the ecosystem of the Banc d' Arguin, Mauritania: a review. Hydrobiologia 258:211-222 